\title{
HOW YOUNG PROFESSIONALS CHOOSE COMPANIES: EMPLOYER BRAND AND SALARY EXPECTATIONS
}

\author{
D. G. KUCHEROV, A. L. ZAMULIN, V. S. TSYBOVA \\ Graduate School of Management, St.Petersburg University, Russia
}

\begin{abstract}
The employer brand concept has been dynamically developing over the past 20 years. Although there are substantial advantages given by the employer brand, its value for specific target groups needs to be explored more deeply. The aim of this article is to identify the key employer brand attributes that are important for young business specialists and to reveal the benefits for the company brought by the employer brand. The empirical research based on mixed methodology (in-depth interviews and a survey among business school bachelor and master program students) was conducted to identify the role of the employer brand in the employment decisions of young specialists and in shaping their salary expectations. The results showed that the jobseekers want to work in the company with the employer brand even if it provides lower wage level. The attributes important for young specialists were found to include both business environment features and internal employer brand characteristics.
\end{abstract}

Keywords: employer brand, employer brand image, employer brand equity, young specialists.

JEL: J40, M39, M55.

Initially the employer brand concept emerged in marketing research and subsequently was adopted by human resource (HR) scholars [Edwards, 2009]. Recruiting and retaining initiatives based on a set of marketing tools [Backhaus, 2016] may enable companies to build long-term mutually beneficial relationships with their current and prospective employees. The goal of the effi- cient recruitment is to find and attract the highly professional and motivated jobseekers who will apply for jobs in an organization [Brown et al., 2003]. One of the key factors in attracting the required professionals is applicants' impressions about a prospective employer, including perceptions of a company attractiveness [Gomes, Neves, 2011].

Postal Address: St.Petersburg State University, Graduate School of Management, 3, Volkhovskiy per., St.Petersburg, 199004, Russia.

(c) D. G. Kucherov, A.L.Zamulin, V.S. Tsybova, 2019

https://doi.org/10.21638/spbu18.2019.102 
Young specialists are the specific jobseekers group within a labor market. Although most of them have a limited amount of real job experience and a lack of professional skills, they have high potential to learn and good motivation to develop themselves and a company. Young specialists are quite sensitive in choosing the employer and pay attention to its attractive attributes represented by the employer brand.

The aim of this article is to identify key employer brand attributes that are important for young business specialists and to reveal the benefits for the company brought by the employer brand. The employer brand message should be aligned with personal and professional needs and values of young specialists. Companies with the employer brand are easily recognized among their competitors and are perceived as the reliable and responsible employers. Such companies are more competitive on the labor market when recruiting and retaining their human resources. Due to their unique attractive image and employer branding activities, they could reduce the HR expenditures [Barrow, Mosley, 2005; Berthon, Ewing, Hah, 2005] and even the compensation costs for the particular groups of employees.

Previous research based separately on quantitative [Bonaiuto et al., 2013; Rampl, Kenning, 2014] or qualitative [Moroko, Uncles, 2008] research design reveals the employer brand attributes that are important for attracting talented graduates. Traditionally these attributes are divided into economic, psychological and functional [Ambler, Barrow, 1996] or instrumental and symbolic [Lievens, Highhouse, 2003]. Our study differs from previous research for the following reasons. First, we use a mix of qualitative and quantitative methods to identify employer brand attributes important for young professionals as well as to explain the key motives of the jobseekers.
Second, following the idea that negative perception of an employer could be caused by single negative experience (e.g. job seekers' experiences with rude or inappropriate recruiters [Rynes, Bretz, Gerhart, 1991]), we anticipate that employer brand trust becomes a key source when explaining employer brand attractiveness [Rampl, Kenning, 2014] and intention of the jobseeker to accept the job offer. Hence, we consider the employer brand as a combination of two assets: employer brand image and employer brand trust. Third, we pay special attention to organization-level outcomes of employer branding initiatives, while most of the researchers examined them on the individual level [Theurer et al., 2018]. In order to investigate the real advantages of the employer brand in a short-term perspective, we measure the level of salary expectations of young professionals. By doing so, we argue that employer brand forms the trust to the employer, which may affect salary expectations of the jobseekers.

The paper is organized as follows. In the first section we review the literature on the specifics of youth labor market in Russia and the concepts of employer brand, employer branding and employer brand evaluation. The second section provides the research methodology and the description of the data. The third section is devoted to the summary of our results. In the fourth section, we present the discussion of the key findings.

\section{The youth labor market in Russia}

The youth labor market covers people between the ages of 15 to 29 [Youth Labour..., 2013; Demidova, Marelli, Signorelli, 2015]. Because of the heterogeneity of this group, it is usually divided into two sub-groups: aged 15-22 and aged 22-29. The first group consists of people who are studying in technical schools and universities, have

RMJ 17 (1): 29-46 (2019) 
no or limited work experience and are often strongly financially attached to their families. The second group graduate specialists, who are likely to have the real work experience some career successes.

The analysis of the contemporary global youth labor market shows the number of important features [Global Employment..., 2017, p.8]:

- a decline of youth proportion in the overall global labor force, from $21.7 \%$ in 1997 to $15.5 \%$ in 2017 ;

- an overall high level of the youth unemployment: $70.9 \mathrm{mln}$ young people are estimated to be unemployed in 2017. Notably, across Organisation for Economic Co-operation and Development (OECD) countries, almost $18 \%$ of unemployed youth have no work for a year or longer;

- youth is to a larger extent involved in informal employment: $76.7 \%$ of working youth have informal jobs, compared with $57.9 \%$ of working adults.

Meanwhile the conditions of digital economy require companies to possess new competencies that the young workers acquire faster. An analysis of six countries (including Russia) on problem solving skills in technology-intensive industries shows that young workers are better equipped to solve problems using technology than adult workers [Global Employment..., 2017].

Although the national economic crisis in Russia (2014-2016) changed the focus of the companies from external recruitment initiatives to internal recruitment, talented external graduates are still of a great importance. The lack of talent is one of the most crucial problems faced by modern companies, along with changing consumer needs and low demand [Hirt, Smit, 2017]. For emerging markets such as Russia, the situation is even more complicated: "Talent in emerging economies... is scarce, expensive and hard to retain" [Dewhurst, Pettigrew, Srinivasan, 2012, p.93]. Contempo- rary Russian labor market is rarely perceived as an attractive for young talents. According to Global Talent Competitiveness Index (GTCI), in 2017 Russia took 56th place among 118 countries that were assessed in terms of attractiveness for young professionals [The Global Talent..., 2017]. Although Russia relies on a solid pool of Global Knowledge Skills (28th rank) and a fine system of Formal Education (30th rank), its biggest challenge continues to be the Talent Attraction (ranked 107th). This explains the high unemployment rate: in 2015-2016 in the 15-19 age group it exceeded $30 \%$, in the $20-24$ age group it was nearly $15 \%$, while the average unemployment rate did not exceed 5-6\% [Zudina, 2017, p.3]. The recommendations given from GTCI included improvement of the Regulatory Landscape (96th rank) and the Business and Labour Landscape (80th rank).

In 2016 the number of vacancies for young specialists on the Russian labor market increased by $16 \%$ whereas the amount of CVs of young job seekers increased only by $5 \%$ [Young Specialist..., 2016]. The decrease in labor supply was mainly caused by the decrease in the number of young people aged 15-24 from $24 \mathrm{mln}$ people in 2002 to $15 \mathrm{mln}$ in 2016 [Russian Statistical Yearbook, 2017]. At the same time, the local business is growing, and the Russian employers are interested in well-educated and experienced young specialists, that is why the unemployment rate for young people aged $15-19$ is higher $(26 \%$ in September 2016) than for the young people aged 20-24 (13.8\% in September 2016) [Russian Statistical Yearbook, 2017]. Currently, at the Russian labor market, every tenth vacancy is for the young specialist.

When looking for the employer, young specialists are very sensitive to the unique employment advantages given by the company. Hence, companies are concerned with 
their attractiveness on the labor market and promote the employer brand in order to attract the talented young specialists.

\section{Employer brand concept}

In its original form the employer brand concept emerged in 1996 in the United Kingdom and was presented in the paper by Ambler and Barrow. They defined the employer brand as "the package of functional, economic and psychological benefits provided by employment, and identified with the employing company" [Ambler, Barrow, 1996, p. 187]. The benefits of the employer brand may be functional (e.g. developmental and work activities), economic (e.g. increased profits) and psychological (e.g. employee attitudes).

In our research, the employer brand concept is closely connected with the following theories: person-organization (P-O) fit, employer image and organizational attractiveness. Based on the idea that both person and environment influence the construction of work attitudes and behaviors [Schneider, 1987], P-O fit takes place when the person and the organization possess similar characteristics [Elving et al., 2013]. Employer image consists of potential applicants' perception of what the organization as an employer will stand for [Lemmink, Schuijf, Streukens, 2003]. Employer image is based on individual perceptions of jobseekers who have an asymmetric information about the particular attributes of the organization as an employer. At the same time companies may send different signals in order to build the positive image perceptions of potential applicants. These signals helps the jobseeker in the decision-making process regarding (1) the consideration the organization as a potential employer and (2) the contact with the organization that may initiate the application process.

The previous studies confirm that $\mathrm{P}-\mathrm{O}$ fit may substentially enhance the attractiveness of an organization regarding specific jobs or organization as a whole [Cable, Judge, 1996; Cable, Edwards, 2004; Elving et al., 2013]. Hence, employer attractiveness is the expected advantages that a potential employee sees in working for a specific organization [Berthon, Ewing, Hah, 2005]. In terms of recruitment when the organization is seen as a desirable place to work, it may more easily attract talented employees.

Companies with the employer brand are positively perceived and are easily recognized by the stakeholders in the labor market. They promote the unique and valuable benefits to target groups and behave as responsible employers fulfilling all obligations to employees [Kucherov, Zavyalova, 2012].

The employer brand establishes the identity of the firm as an employer [Backhaus, Tikoo, 2004] and facilitates the formation of employees' professional identities [Gardner, Erhardt, Martin-Rios, 2011]. This is especially important for a young talents who is looking for the "right" job, occupation and organization. Young professionals take into account different organizational attributes when comparing and choosing the suitable employers.

Currently, the youth are attributed to the "Generation Y" or Millennials. This generation group is quite specific in terms of their personal and professional needs, values and aspirations. Millennials are independent, individualistic, socially active, have the high level of self-reliance and like to work in teams [Shih, Allen, 2007]. They are mobile, value joy at work and demonstrate higher level of confidence and selfesteem [Taylor, 2014]. The global study by the INSEAD Emerging Markets Institute, the HEAD Foundation and Universum among 16000 Millennials in 43 countries revealed that for $41 \%$ of the respondents it was very important to become a leader or a manager. Younger Millennials stessed the interest in coaching and mentoring as

RMJ 17 (1): 29-46 (2019) 


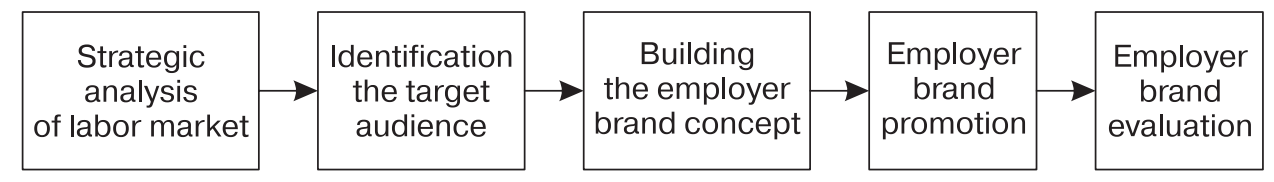

Fig. 1. Employer branding framework

a part of a leadership role [Bresman, 2014]. In addition, Millennials' main focus was to grow and learn new things (45\%), which was the second most important factor after work-life balance. In addition, $73 \%$ of the surveyed professionals chose work-life balance over a higher salary and $82 \%$ picked a better work-life balance over their career advancements in a company, while $42 \%$ would have preferred to have no job than to have one they hated. The biggest fear for $40 \%$ of respondents globally was getting stuck in a job with no development opportunities.

The Gallup's report “How Millennials want to work and live" [Adkins, 2016] found that Millennials struggled to find good jobs that engaged them. Millennials had the highest rates of unemployment and underemployment in the U.S., so that only $29 \%$ of employed Millennials were engaged at work. In addition, four key characteristics of Millennials were identified: unattached, connected, unconstrained and idealistic. They are the group without attachments and they do not feel close ties to their jobs. At the same time, they are highly connected with the external world. Millennials see work and life as closely intertwined. Finally, they are a largely optimistic group, and they believe that life and work should be worthwhile and have the meaning.

In similar vein, the research [Renaud, Morin, Fray, 2016] among 339 final-year business undergraduates from two Canadian universities found that both ethics and training had a large effect on applicant attraction, whereas workplace perks (for example, onsite gym or medical clinic) had only a small effect. These findings corresponded to the idea that offering training opportunities help to meet the expectations of the employees and contribute to their sense of organizational commitment [Bulut, Culha, 2010].

\section{Employer branding}

Employer branding as a process involves identifying the unique "employment experience" by considering the totality of tangible and intangible rewards offered by a firm [Edwards, 2009]. It is aimed to present a positive and attractive image to both jobseekers and current employees [Backhaus, 2016]. Employer branding has the potential to attract the best talent from the external labor market that best fits the organisations [Harris, Short, 2014]. We propose the following framework of the employer branding (Figure 1).

Within the first stage, firms conduct the strategic analysis of the labor market. It involve the environmental analysis of the external labor market as well as of the analysis of the internal labor market. General current trends on the national labor market (changes in population, employment, unemployment, migration) and labor market of the company's industry (labor market structure, quality of human capital, labor supply and labor demand) are usually considered. The internal labor market review should help to answer the questions "Which employees do we need?" and "How many employees do we need?" with the given business strategy, HR strategy and limitations of HR budget. Thus, the activities of the 
first stage help to bring out the further core employer branding goals: to attract candidates, to engage employees or to retain employees.

Next, based on labor market segmentation, the target audience for the employer brand should be identified. The factors for the employer branding segmentation could be divided into two groups: observable and unobservable [Moroko, Uncles, 2009]. The observable factors are age, seniority, job type, permanence, employee lifecycle, tenure, physical location. The unobservable factors consist of career focus, outlook on life stage, desired career benefits.

By making the survey among the target audience representatives their dominant working needs, values and expectations are explored. This is the basis for building the employer brand concept. Employer brand concept has two main layers. First, employer branding messages should communicate accurate information about the culture and main corporate values of the company [Backhaus, Tikoo, 2004]. Second, it enables the target audience to easily identify the employer's name, logo, sign symbol and differentiate them from the those of direct competitors in the labor market. Hence, efficient employer branding leads to the strong positive perception of the company as a "great place to work" among others [Ewing et al., 2002]. To achieve this, companies need to create a strong employer value proposition (EVP), which is a message of the key benefits offered by the firm that relates specifically to the needs of external and internal labor markets [Mosley, 2007; Moroko, Uncles, 2008]. Besides, the company needs to choose whether it produces one common EVP for all target groups or makes different propositions to different employee groups, depending on their value creation potential and uniqueness [Becker, Huselid, Beatty, 2009]. Thus, employer branding process is about creating and developing employment propositions which are unique, compelling and relevant to the target audience [Minchington, 2014].

At the next stage, companies promote their EVP. EVP represents desired or ideal employer identity, i. e. how the company wants to be perceived by target audience as an attractive employer [Theurer et al., 2018]. The most popular mediums to communicate the EVP are social media, career website, training and development programs, internal newsletters, employee referral programs and online job boards [Minchington, 2014]. The final stage is the evaluation of the resulted employer brand.

\section{Employer brand evaluation: Current approaches and research framework}

One of the first attempts to explore the employer branding outcomes was presented in the framework by [Backhaus, Tikoo, 2004]. This framework is based on two employer brand assets. The first outcome is an employer brand image developed by potential employees from the employer brand associations. An employer brand image affects the attractiveness of the organization to the job seekers. The second outcome is the employer brand loyalty that emerges due to the strong organization culture and organization identity.

Following employer branding framework of [Backhaus, Tikoo, 2004], [Minchington, 2010] developed the model of employer brand equity consisting of four core employer brand assets: employer brand awareness, associations, loyalty and perceived employment experience. Employer brand awareness is the level of recognition people have about an organization's positive and negative employment attributes. Employer brand associations include the ideas of current and prospective employees about rational and emotional employment attributes. Employer brand loyalty refers to the individual's commitment to join or remain employed in an organization. Perceived employ-

RMJ 17 (1): 29-46 (2019) 


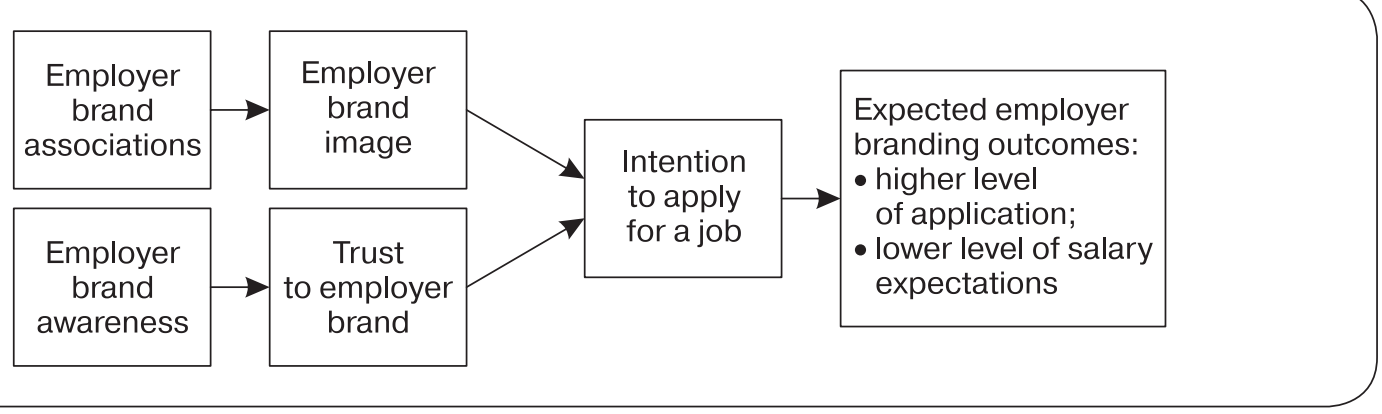

Fig. 2. Conceptual framework for the research

ment experience is the association employees have about working for an organization based upon the online and offline touchpoints the person interacts with [Kucherov, Samokish, 2016].

In our research, we focus on the young specialists who are looking or going to look for the job. Therefore, in this paper, the primary employer brand asset is the employer brand image. We define it as the perceptions and associations of potential applicants regarding the company's employer brand [Kucherov, Samokish, 2016]. Following Knox and Freeman, we stress that "the employer brand image is a particularly significant predictor of early decisions made by new recruits about their employers" [Knox, Freeman, 2006, p. 698].

The second employer brand asset that we consider is employer brand awareness, which is rooted in psychological contract theory. Psychological contracts are the subjective "expectations about the reciprocal obligations that compose an employee-organization exchange relationship" [Morrison, Robinson, 1997]. We expect the companies with the employer brand to be ready to perform all the obligations (promises) to potential employees. It means that such companies are responsible and reliable employers and abide with the conditions of the psychological contract. Therefore, they are overall positively recognized by the jobseekers. To summarize, Figure 2 presents our conceptual framework.
As can be seen, employer brand image is constructed by the number of positive associations about job and organizational attributes of the particular employer. Employer brand awareness could lead to the stable perception to the company as a trustworthy employer. This feeling of trust could be based on real direct (job fairs, internship experience, guest lectures and other training initiatives in universities) or indirect experience of the applicant. Both employer brand image and trust to employer brand influence applicant attraction to organization. Hence, we expect two positive outcomes for the company. First, the greater amount of young talented professionals is expected to apply for the job. Secondly, we anticipate that their salary expectations will be lower given that they receive better work experience in the company with the employer brand.

Based on the discussion above, in this research we ask:

Research question 1. What employer brand attributes are important for young specialists when looking for the job?

Research question 2. What are the salary expectations of young specialists who choose to work in the company with the employer brand?

\section{Methodology}

Our research was based on mixed research methodology and consisted of two stages. 
In the first stage in order to answer the research question 1 and clarify our research framework we conducted exploratory in-depth interviews. We chose the qualitative research design because we were interested in collecting "facts" and understanding the opinions and attitudes of young specialists in choosing the best employer [Rowley, 2012]. The topic for the interview was "The employer of my dream". As the most appropriate style we chose the narrative interview. Narrative interviewing is understood as a dynamic approach used to generate stories as a data source, which help gain access to a participant's actual life experience [Duffy, 2007]. We expected to collect the real stories of the young specialists related to search and choice of the most suitable employer as well as their perception of the most attractive company to work for.

The average length of the interview was approximately half an hour. Each interview was carried out with one interviewee by one interviewer. In the beginning, we established the specific framework for the discussion in the following way: "Dear Respondent! Today we would like to talk with you about the employer of your dream. We would like to understand what is important for you when looking for the employer, the occupation and the job you dream of. What characteristics of the employer are most important for you and why? Any comments are important to us". Then the interviewee expressed his/her vision of the employer of the dream in a free form. All the interviews were recorded. When it was necessary, the interviewees was asked several specifying questions at the end of the meeting.

In order to answer research question 2 , we prepared a short experiment-based questionnaire. It contained demographics section (age, gender, working experience), the description of two fake companies and a sequential set of questions to the respondents of their perception of these companies. Descriptions of companies were developed in accordance to the Employer Attractiveness Scale [Berthon, Ewing, Hah, 2005]. In the description of each organization, we noted that both companies propose attractive benefits and working conditions to their employees (the examples of these benefits are "Happy work environment", "An attractive overall compensation package”, "Good promotion opportunities within the organization", "Gaining career-enhancing experience"). The descriptions were identical with the exception of one feature: the first company was described as an organization with a stable positive reputation in the labour market which carried out all of its obligations to employees; the second one was portrayed as an organization with also a good reputation but with some negative opinions in the labour market about it. Thus, the first company possessed the employer brand (CEB), while the second was the company without the employer brand (CWEB).

We asked our respondents three questions.

1. In which company, the first (CEB) or the second (CWEB), would you like to work? Explain your choice.

2. For what salary would you like to work in your company?

3. For what salary would you like to work in the second company, if you are not hired by the first one?

In the last two questions we proposed the salary range from 15000 rub. (about 250 eur.) to 150000 rub. (about 2200 eur.) [Kucherov, Zavyalova, 2012].

\section{Sample}

In the first stage, we conducted in total 26 in-depth interviews with second year master program business students from the Graduate School of Management (St. Petersburg, Russia). In the second stage, we collected 133 valid questionnaires from the

RMJ 17 (1): 29-46 (2019) 
Table 1

Sample description

\begin{tabular}{l|l|c|c|c}
\hline \multicolumn{2}{c|}{ Sample characteristics } & \multicolumn{3}{c}{ Level of education } \\
\cline { 3 - 5 } \multicolumn{2}{l|}{} & $\begin{array}{c}\text { Bachelor, \% } \\
(\boldsymbol{N}=\mathbf{1 0 7})\end{array}$ & $\begin{array}{c}\text { Master, \% } \\
(\boldsymbol{N}=\mathbf{2 6})\end{array}$ & $\begin{array}{c}\text { All, \% } \\
(\boldsymbol{N}=\mathbf{1 3 3})\end{array}$ \\
\hline Gender & Male & 35.51 & 38.46 & 36.09 \\
& Female & 64.49 & 61.54 & 63.91 \\
\hline Age & 19 & 2.80 & - & 2.26 \\
& 20 & 42.06 & - & 33.83 \\
& 21 & 43.93 & 3.85 & 36.09 \\
& 22 & 10.28 & 26.92 & 13.53 \\
& 23 & 0.93 & 26.92 & 6.02 \\
& 24 & - & 15.38 & 3.01 \\
& 25 & - & 11.54 & 2.26 \\
& 26 & - & 11.54 & 2.26 \\
& 27 & - & 3.85 & 0.75 \\
\hline Working experience & Less than 3 months & 47.66 & 11.54 & 40.60 \\
& $3-12$ months & - & - & - \\
& More than 1 year & 52.34 & 88.46 & 59.40 \\
\hline
\end{tabular}

Bachelor (107) and the Master (26) students of the same business school. All of the Master students were studying in the full-time international management master program taught in English whereas the Bachelor students were the full-time management students (with the different specialization: HR Management, Finance, Logistics, Information Technologies, Public management). At the moment of interview, the Master students had at least one semester of study abroad. All the students had the real job experience such as summer internships, part-time or full-time work. The respondents were young business specialists with fluent English and often a real work experience.

Table 1 represents information about the respondents. Most respondents are bachelor students $(80 \%)$. Almost $60 \%$ of the respondents are female. The age of respondents ranged from 19 to 27 years old (around 85\% were 20-21 years old). $88 \%$ of Master students had the working experience of more than 1 year, the working experience of remaining 12\% was less than 3 months. Among Bachelor students shares of the respondents with less than 3 months and more than 1 year working experience are $47.66 \%$ and $52.34 \%$ accordingly.

\section{Results}

\section{Results of the qualitative research}

\section{Business environment}

Many respondents started their talk by stressing the importance of the business environment where the preferred employer operated. Typical answers were:

"Firstly, the industry where the company operates is especially interesting for me. I tend to appreciate dynamic, changing environments which demand strategic thinking of the company. The difference can be felt even as an intern. The tasks and the thinking approaches get more complex and challenging when the firm sees itself in a dynamic market where competing is very important. Furthermore, $d y$ namic markets tend to develop more innovations which shape the market completely in a new way and I am interested in finding out and reading about innovations".

Exchange program student, female, 24 years old 
"When it comes to the company as a whole, I know that I strongly profit from an ambitious and competitive environment. I am not a person who is scared off by competition and challenges. I grow with them".

Exchange program student, female, 23 years old

The respondents valued the competitive business environment and are not afraid of its unpredictable, dynamic nature. Rather, they it as something that tests their professional capacities, stress resistance and problem-solving competencies.

Interviewees also evaluated the industry and the products of the company as important:

"The industry is also important for me. I want to spend my life doing things in which I believe, things which I consider useful. This is why if I choose the company, firstly I will choose the industry".

Full-time program student, female, 23 years old

"I value complicated products with high involvement over low involvement products".

Exchange program student, female, 22 years old

These statements reflect the aspirations of the respondents to build the distinctive professional identity by choosing the "right" industry and product that are congruent with their personal values.

Finally, the scope of activities was important. Large multinational corporations were often mentioned as the first-choice employer:

"First of all, I would like to work in an international company with a long experience of work in its sphere. I am expecting to work in a company which has headquarters abroad and expanded their business in Russia".

Full-time program student, male, 24 years old
"It should be an international company. So, I am only in the beginning of my career, I appreciate all cross-border opportunities that a company can provide. An experience shows that it is easier to move to another country within the same company you are working for".

Full-time program student, female, 22 years old

These preferences could be explained respondents' stereotypes that international companies are more stable, reliable and propose better career opportunities.

\section{Internal employer brand attributes}

Following the idea of Ambler and Barrow that an employer brand is the package of functional, economic and psychological benefits, we were also concerned with the particular set of internal tangible and intangible employer brand attributes which were important for the respondent.

In rare cases the salary itself was the paramount factor. More often, respondents wanted to receive "enough money to live decently", "transparent and strict salary", "competitive salary" or "medium or higher than medium salary". At the same time, respondents paid attention to the social package. The list of such social benefits was quite long and included corporate cars, voluntary medical insurance, treatment centers, mortgage loans, pension programs, stock options, meals and transportation compensation.

Majority of the respondents stressed the importance of psychological and functional employer brand attributes:

"My ideal employer has to provide me agile working conditions. I am concerned that strict hours, fixed working place, dress-code and schedule has gone past and not effective anymore. People have to be responsible for the result of their work and not for the schedule and attendance".

Full-time program student, male, 23 years old 
"I want the company to take care about the happiness of the employee in the organization”.

Full-time program student, female, 23 years old

Organizational culture and values that fit the personal needs of the respondent was seen as a crucial in building long-term employment relationships. In almost every interview the respondents mentioned cultural issues:

"A multilingual and international culture that places emphasis on creativity, trust, and innovative thinking would definitely make an ideal employer".

Exchange program student, male, 23 years old

"I value a company culture in which every opinion is respected. The company culture should be open to new ideas and everyone should be able to shape his or her opinion".

Exchange program student, female, 24 years old

"The employer should have the same values that I do. The discrepancies in perceiving the world might cause various disagreements throughout the work process".

Full-time program student, female, 22 years old

The respondents also paid large attention to training and development opportunities:

"A responsible employer is the one who cares about its employees and their career perspectives and expectations".

Full-time program student, female, 23 years old

"First of all, an opportunity to grow and develop both in my professional area and personally is incredibly important for me. This opportunity should not only be expressed formally under the company's mission and vision statement, but should really be implemented within the organizational structure and daily activities".

Full-time program student, female, 24 years old
"My ideal employer is someone who has mentoring skills. A mentor that is able to transfer technical and practical knowledge".

Exchange program student, male, 23 years old

Summing up, for most of our respondents "the employer of their dream" is the company with open and innovative culture that supports personal and career growth of its employees and is flexible in terms of working conditions.

\section{Results of the quantitative research}

In our questionnaire we compared the images of the CEB and the CWEB and two salary options: Salary 1 indicates the salary that students want to receive working in the company of their first choice, and Salary 2 is a wage in the second-choice company (Table 2).

Results of our study illustrate that majority of Bachelor and Master students prefer to work for the CEB for the relatively lower salary: $88 \%$ of Bachelor students and $92 \%$ of Master students. However, their salary expectations increased up to $33 \%$ for Bachelor and up to $14 \%$ for Master students, if they chose the CWEB. At the same time for both student groups the salary expectations decreased if they had to work in the CEB instead of the CWEB. Those students who preferred the CWEB as their first choice explained such decision by one of the following reasons:

- only positive reviews about the CEB look suspicious;

- willingness and interest to overcome difficulties in the CWEB;

- in the CWEB there will be less competition between employees and more opportunities for creative work.

Table 3 presents the distribution of choices among different groups of respondents. Male Bachelor and Master students would like to receive higher salary in comparison with female students. However, the difference 


\section{Table 2}

Student's choice of the company and preferable salary

\begin{tabular}{l|c|c|c}
\hline & $\begin{array}{c}\boldsymbol{N} \\
(\%)\end{array}$ & $\begin{array}{c}\text { Salary 1, } \\
\text { thousands of rub. }\end{array}$ & $\begin{array}{c}\text { Salary 2, } \\
\text { thousands of rub. }\end{array}$ \\
\hline Bachelor students & $107(100)$ & & \\
CEB & $94(88)$ & 57.3 & 79.0 \\
CWEB & $13(12)$ & 90.2 & 75.9 \\
\hline Master students & $26(100)$ & & \\
CEB & $24(92)$ & 91.4 & 106.3 \\
CWEB & $2(8)$ & 77.5 & 71.5 \\
\hline
\end{tabular}

N o t e: CEB - the company with employer brand, CWEB - the company without emploer brand.

Table 3

Student's choice of the company and preferable salary by gender and working experience

\begin{tabular}{|c|c|c|c|c|c|}
\hline Education level $(N)$ & Category & Number $(N)$ & $\begin{array}{c}\text { Salary 1, } \\
\text { thousands of rub. }\end{array}$ & $\begin{array}{c}\text { Salary 2, } \\
\text { thousands of rub. }\end{array}$ & $\begin{array}{c}\Delta, \text { thousands } \\
\text { of rub. }\end{array}$ \\
\hline \multirow{4}{*}{$\begin{array}{l}\text { Bachelor students } \\
\text { (107) }\end{array}$} & \multirow[t]{2}{*}{ Gender } & Male (38) & 69.0 & 89.1 & 20.1 \\
\hline & & Female (69) & 54.4 & 75.6 & 21.2 \\
\hline & \multirow[t]{2}{*}{$\begin{array}{l}\text { Working } \\
\text { experience }\end{array}$} & $\begin{array}{l}\text { Without working } \\
\text { experience }(51)\end{array}$ & 55.9 & 78.4 & 22.5 \\
\hline & & $\begin{array}{l}\text { With working } \\
\text { experience }(56)\end{array}$ & 58.6 & 79.7 & 21.1 \\
\hline \multirow{4}{*}{$\begin{array}{l}\text { Master students } \\
\text { (26) }\end{array}$} & \multirow[t]{2}{*}{ Gender } & Male (11) & 112.3 & 124.1 & 11.8 \\
\hline & & Female (15) & 81.6 & 99.0 & 17.4 \\
\hline & \multirow[t]{2}{*}{$\begin{array}{l}\text { Working } \\
\text { experience }\end{array}$} & $\begin{array}{l}\text { Without working } \\
\text { experience }(4)\end{array}$ & 48.0 & 79.7 & 31.7 \\
\hline & & $\begin{array}{l}\text { With working } \\
\text { experience }(22)\end{array}$ & 103.1 & 115.3 & 12.2 \\
\hline
\end{tabular}

between Salary 1 and Salary 2 is higher for female students. For Bachelor and Master students the differences between Salary 1 and Salary 2 is higher for the students without working experience. At the same time all students with working experience are eager to have higher salary for both choices than students without experience.

We also conducted correlation analysis to check the conclusions of previous analysis. We used biserial correlation coefficient that is the modification of Pearson's correlation due to the type of variables (dichotomy and interval) (Table 4).
The results of correlation analysis demonstrated a significant positive direct relation between age, level of education and the student's choice; however, this relation is quite weak. At the same time, the relationship between working experience and the student's choice is also positive and direct, but it's not significant.

\section{Discussion and conclusion}

We investigated the role of the employer brand image and employer brand awareness in employment decisions of young special- 
Table 4

\section{Correlation matrix}

\begin{tabular}{l|c|c|c|c|c|c}
\cline { 2 - 7 } & Choice & Experience & Gender & Age & Specialization & Level \\
\hline Choice & 1.0000 & & & & & \\
\hline Experience & 0.0372 & 1.0000 & & & & \\
\hline Gender & -0.1217 & 0.1431 & 1.0000 & & & \\
\hline Age & $0.1483^{*}$ & $0.2911^{* * *}$ & 0.0409 & 1.0000 & & \\
\hline Specialization & -0.1240 & $-0.2130^{* *}$ & $0.1661^{*}$ & $-0.4919^{* * *}$ & 1.0000 & \\
\hline Level & $0.1622^{*}$ & $0.2917^{* * *}$ & 0.0243 & $0.7691^{* * *}$ & $-0.6200^{* * *}$ & 1.0000 \\
\hline
\end{tabular}

Note: $* * *$ and $* * *$ indicate significance at the $10 \%, 5 \%$ and $1 \%$, respectively.

ists using mixed methodology, containing qualitative (in-depth interviews) and quantitative (survey data) techniques

The employer brand image is developed "from the brand associations that are an outcome of a firm's employer branding" [Backhaus, Tikoo, 2004]. These associations are closely connected to the "employer attractiveness", i.e. the expected advantages that an applicant sees in working for a specific organization [Berthon, Ewing, Hah, 2005]. Our findings suggest that young specialists are very sensitive to the corporate profile - they prefer companies operating in changing environment and dynamic markets. At a more personal level, young jobseekers valued the development opportunities provided by a company. This corresponds with the previous studies, in which the development of skills and career-enhancing experiences are identified as being valuable for "Generation Y" employees [Reis, Braga, 2016]. Our results also demonstrate that in Russia young business specialists appreciate open and innovative culture, which is in line with the findings of [Magun, Rudnev, 2012].

Employer brand awareness reflects the brand "node strength in memory and how easily the brand comes in mind" [Theurer et al., 2018]. It is closely connected to the organization's positive and negative employment attributes recognized by the jobseekers [Minchington, 2010]. We show that the CEBs will provide more attractive psycho- logical contract [Edwards, 2009]. In other words, the CEBs are responsible for fulfilling the explicit contractual terms and implicit unwritten agreements or obligations offered to the jobseekers during the recruitment and selection stages. This corresponds with the previous studies stating that Millennials often focus on the ethical considerations when considering potential employers [Jones, Ahmad, 2011]. The results of the survey confirm that the CEB is the preferable company to work for the most respondents. It is perceived as a stable, responsible and reliable employer which fulfills its obligations to employees and is seen as mostly positive both by internal and external stakeholders. As a result, the applicants were ready to tolerate lower wage level working in the CEBs. Conversely, working in the CWEBs, young professionals would require higher salary to reduce the risks. These results strongly support the previous studies that suggest that the CEBs could offer lower payment to employees in similar positions in comparison with the CWEBs [Berthon, Ewing, Hah, 2005; Kucherov, Zavyalova, 2012].

We further develop the literature in employer attractiveness and employer branding by showing what particular employer brand assets lead to positive recruitment outcomes of young professionals. Going beyond the framework of [Backhaus, Tikoo, 2004] we specify "trust to employer brand" 
as an important antecedent the job application process. As for employer brand image, our results demonstrate the set of important attributes taken into the account by young professionals when choosing the employer. The set contains not only economic, psychological and functional benefits, but also the overall corporate profile of the employer.

\section{Managerial implications}

The issues addressed in this research offer several managerial implications. First, companies interested in efficient recruiting of young business professionals have to build a holistic EVP consistent with its business environment and attractive internal brand attributes. It means that company's attractiveness is perceived not only by its distinctive instrumental and symbolic attributes [Lievens, Highhouse, 2003], but also by its offerings and industrial profile and international activities. Additionally, the content of work plays an important role for young specialists. Jobseekers evaluate whether the work is team-based, project-oriented and creative or boring and monotonous. At the same time, the EVP should be consistent with what the organization actually is [Elving et al., 2013]. As seen from our survey, the respondents were quite sensitive to the fact that the employer carried out all of its obligations to employees. Hence, they perceived it as reliable employer, which is the basis for strong psychological contract in the initial recruiting stages.

Second, to better communicate employer brand to potential applicants, companies should choose the "right" communication channels. This is the key factor in building the high employer brand awareness. For example, social media become very popular among young people. At the same time, "jobseekers perceive information to be more credible on company-controlled social media sites than on independent sites" [Kissel, Büttgen, 2015, p.770]. The other efficient channels may involve job fairs, career days in universities, branding through ambassadors (e.g. interns or new full-time young employees) and various forms of company participation in university courses.

Thirdly, due to the lower salary expectations of the young jobseekers the CEBs could be more flexible in terms of managing salaries. But this does not mean the company should only decrease the wage budget, especially within the crisis periods. Rather, it is an opportunity to redistribute company's HR costs from payroll to training and development initiatives. Our research revealed that young business professionals expect higher investments in their personal and career growth. At the same time, CEBs need to identify the most valuable group of young high potential or high performance professionals. This group can be managed as a loyal and strongly committed to the employer and may be provided with particular training and development programs.

\section{Limitations and future research}

The present study has several limitations. Our sampling involved only the Russian business students. Hence, we cannot generalize our findings to the students groups with other educational background. Further research is needed for comparative analysis of "tastes" and expectations regarding the potential employer among students with different educational background.

Further, the finding about the lower salary expectations of the young jobseekers for the CEB cannot be generalized to other target groups. The experienced professionals, who have broad professional competencies and their own well-known personal brand, could be less sensitive to the employer brand influence. Hence, they could be more demanding regarding the level of salary and other monetary rewards. Future research may identify how important the employer brand for experienced professionals is.

RMJ 17 (1): 29-46 (2019) 


\section{REFERENCES}

Adkins A. 2016. What Millennials Want from Work and Life. Gallup. [Electronic resource]. http://www.gallup.com/businessjournal/191435/millennials-work-life.aspx (accessed: 28.11.2018).

Ambler T., Barrow S. 1996. The employer brand. Journal of Brand Management 4 (3): $185-206$.

Backhaus K. 2016. Employer branding revisited. Organization Management Journal 13 (4): 193-201.

Backhaus K., Tikoo S. 2004. Conceptualizing and researching employer branding. $\mathrm{Ca}$ reer Development International 9 (5): 501517.

Barrow S., Mosley R. 2005. The Employer Brand. Bringing the Best of Brand Management to People at Work. John Wiley \& Sons: Chichester.

Becker B.E., Huselid M.A., Beatty R.W. 2009. The Differentiated Workforce: Transforming Talent into Strategic Impact. Harvard Business Review Press: Boston, MA.

Berthon P., Ewing M., Hah L.L. 2005. Captivating company: Dimensions of attractiveness in employer branding. International Journal of Advertising 24 (2): 151172.

Bonaiuto M., De Dominicis S., Illia L., Rodríguez-Cánovas B., Lizzani G. 2013. Managing employer brand attributes to attract potential future leaders. Journal of Brand Management 20 (9): 779-792.

Bresman H. 2014. Millennials Want to Lead. Are They Ready? INSEAD Knowledge. [Electronic resource]. https://knowledge. insead.edu/leadership-management/millennials-want-to-lead-are-they-ready-3692 (accessed: 28.11.2018).

Brown D.J., Levy P.E., Cober A.B., Cober R.T., Keeping L.M. 2003. Organizational web sites: Web site content and style as determinants of organizational attraction. International Journal of Selection and Assessment 11 (2-3): 158-169.

Bulut C., Culha O. 2010. The effects of organizational training on organizational com- mitment. International Journal of Training and Development 14 (4): 309-322.

Cable D. M., Edwards J.R. 2004. Complementary and supplementary fit: A theoretical and empirical integration. Journal of Applied Psychology 89 (5): 822-834.

Cable D. M., Judge T. A. 1996. Person-organization fit, job choice decisions and organizational entry. Organizational Behavior and Human Decision Processes 67 (3): 294-311.

Demidova O., Marelli E., Signorelli M. 2015. Youth labour market performances in the Russian and Italian regions. Economic Systems 39 (1): 43-58.

Dewhurst M., Pettigrew M., Srinivasan E. 2012. How multinationals can attract the talent they need? McKinsey Quarterly 3 (8): $92-99$.

Duffy M. 2007. Narrative inquiry: The method. In: P. L. Munhall. Nursing Research: A Qualitative Perspective. Bartlett and Jones Learning: Sudbury, MA.

Edwards M.R. 2009. An integrative review of employer branding and OB theory. Personnel Review 39 (1): 5-23.

Elving W.J.L., Westhoff J.C., Meeusen K., Schoonderbeek J.-W. 2013. The war for talent? The relevance of employer branding in job advertisements for becoming an employer of choice. Journal of Brand Management 20 (5): 355-373.

Ewing M.T., Pitt L.F., de Bussy N.M., Berthon P. 2002. Employment branding in the knowledge economy. International Journal of Advertising 21 (1): 3-22.

Gardner T.M., Erhardt N.L., Martin-Rios C. 2011. Rebranding employment branding: Establishing a new research agenda to explore the attributes, antecedents, and consequences of workers' employment brand knowledge. In: A. Joshi, H.Liao, and J.J. Martocchio. Research in Personnel and Human Resources Management Vol.30; 253-304. Emerald Group Publishing Limited: N.Y.

Global Employment Trends for Youth 2017: Paths to a Better Working Future. 2017. 
International Labor Organization. [Electronic resource]. http://www.ilo.org/wcm sp5/groups/public/---dgreports/---dcomm/--publ/documents/publication/wcms_598669. pdf (accessed: 03.03.2019).

Global Talent Competitiveness Index 2017. 2017. INSTEAD. [Electronic resource]. https://www.insead.edu/news/ 2017-global-talent-competitiveness-index-davos (accessed: 03.03.2019).

Gomes D., Neves J. 2011. Organizational attractiveness and prospective applicants' intentions to apply. Personnel Review $\mathbf{4 0}$ (6): 684-699.

Harris R., Short T. (eds). 2014. Workforce Development. Perspectives and Issues. Springer: N.Y.

Hirt M., Smit S. 2017. Economic Conditions Snapshot, March 2017: McKinsey Global Survey Results. McKinsey Quarterly.

Jones S., Ahmad A. 2011. The Perception of Employer Value Propositions and the Contrast Between Dutch and Chinese Graduates: A Case Study of TNT. Emerald Emerging Markets Case Studies, doi.org/10.1108/ 20450621111117125.

Kissel P., Büttgen M. 2015. Using social media to communicate employer brand identity: The impact on corporate image and employer attractiveness. Journal of Brand Management 22 (9): 755-777.

Knox S., Freeman C. 2006. Measuring and managing employer brand image in the service industry. Journal of Marketing Management 22 (7-8): 695-716.

Kucherov D., Samokish V. 2016. Employer brand equity measurement. Strategic $H R$ Review 15 (1): 29-33.

Kucherov D., Zavyalova E. 2012. HRD practices and talent management in the companies with the employer brand. European Journal of Training and Development 36 (1): 86-104.

Lemmink J., Schuijf A., Streukens S. 2003. The role of corporate image in explaining application intentions. Journal of Economic Psychology 24 (1): 1-15.

Lievens F., Highhouse S. 2003. The relation of instrumental and symbolic attributes to a company's attractiveness as an employer. Personnel Psychology 56 (1): 75-102.

Magun V.S., Rudnev M.G. 2012. The basic values of two generations of Russians and the dynamics of their social determination. In: E. G. Yasin (ed.). XII International Scientific Conference on Economic and Social Development. Book 3; p.87-97. Moscow: HSE Publishing House. (In Russian)

Minchington B. 2010. Employer Brand Leadership: A Global Perspective. Collective Learning, Torrensville, Australia.

Minchington B. 2014. 2014 Employer Branding Global Trends. Study Report. Employer Brand International, Torrensville, Australia.

Moroko L., Uncles M.D. 2008. Characteristics of successful employer brands. Journal of Brand Management 16 (3): 160-175.

Moroko L., Uncles M.D. 2009. Employer branding and market segmentation. Journal of Brand Management 17 (3): 181196.

Morrison E.W., Robinson S.L. 1997. When employees feel betrayed: A model of how psychological contract violation develops. Academy of Management Review 22 (1): 226-256.

Mosley R.W. 2007. Customer experience, organisational culture and the employer brand. Journal of Brand Management 15 (2): 123134.

Rampl L.V., Kenning P. 2014. Employer brand trust and affect: Linking brand personality to employer brand attractiveness. European Journal of Marketing 48 (1/2): 218-236.

Reis G.G., Braga B.M. 2016. Employer attractiveness from a generational perspective: Implications for employer branding. Revista de Administração 51 (1): 103116.

Renaud S., Morin L., Fray A. M. 2016. What most attracts potential candidates? Innovative perks, training, or ethics? Career Development International 21 (6): 634-655.

Rowley J. 2012. Conducting research interviews. Management Research Review 35 (3/4): 260-271.

RMJ 17 (1): 29-46 (2019) 
Russian Statistical Yearbook. 2017. Federal State Statistics Service (Rosstat). [Electronic resource]. http://www.gks.ru/wps/ wps/wcm/connect/rosstat_main/rosstat/ $\mathrm{ru} /$ statistics/publications/catalog/doc_113 5087342078 (accessed: 28.11.2018). (In Russian)

Rynes S.L., Bretz R.D., Gerhart B. 1991. The importance of recruitment in job choice: $\mathrm{A}$ different way of looking. Personnel Psychology 44 (3): 487-521.

Schneider B. 1987. The people make the place. Personnel Psychology 40 (3): 437-453.

Shih W., Allen M. 2007. Working with Generation-D: Adopting and adapting to cultural learning and change. Library Management 28 (1/2): 89-100.

Taylor T. 2014. Millennials are ready to tackle challenge. Public Management 96 (8): 52-55.

Theurer C.P., Tumasjan A., Welpe I. M., Lievens P. 2018. Employer branding: A brand equity-based literature review and research agenda. International Journal of Management Reviews 20 (1): 155-179.

Young Specialists at the Russian Labour Market. 2016. Career.ru. [Electronic resource]. https://pandia.ru/text/80/541/4364.php (accessed: 28.11.2018). (In Russian)

Youth Labour Market Analysis: A Training Package on Youth Labor Market Information. 2013. International Labour Organization. [Electronic resource]. http://www.ilo. org/wcmsp5/groups/public/---ed_emp/--emp_policy/documents/instructionalmaterial/wcms_302416.pdf (accessed: 03.03. 2019).

Zudina A.A. 2017. "They Don't Work and Don't Study": NEET Youth on the Russian Labour Market. Working paper WP3/ 2017/02. Moscow: HSE Publishing House. (Series WP3 "Labour Markets in Transition”). (In Russian)

Initial Submission: January 22, 2019

Final Version Accepted: March 7, 2019

\section{Как лолодые специалисты выбирают колпании: бренд работодателя и зарплатнье ожидания}

\section{Д. Г. Кучеров, А.Л. Залулин, В.С.Цибова}

Институт «Высшая школа менеджмента» Санкт-Петербургского государственного университета, Россия

Концепция бренда работодателя динамично развивается на протяжении последних 20 лет. Хотя общий перечень преимуществ, обеспечиваемых брендом работодателя, весьма разнообразен, требуется его более детальная эмпирическая проверка для конкретных целевых групп. Цель данной статьи заключается в определении атрибутов бренда работодателя, важных для молодых специалистов в сфере бизнеса, а также тех преимуществ, которые компания благодаря ему приобретает. Эмпирическое исследование, основанное на смешанной методологии (26 глубинных интервью и анкетный опрос 133 студентов программ бакалавриата и магистратуры), предполагало выявление роли бренда работодателя в принятии молодыми специалистами решения о трудоустройстве и в формировании их зарплатных ожиданий. Результаты исследования показали, что большинство опрошенных хотят работать в компании с брендом работодателя, даже если это сопряжено с более низким уровнем оплаты труда. Важные атрибуты бренда работодателя, принимаемые во внимание молодыми специалистами, включают как особенности внешней бизнес-среды, так и внутренние характеристики работы. 
Ключевые слова: бренд работодателя, имидж бренда работодателя, капитал бренда работодателя, молодые специалисты.

JEL: J40, M39, M55.

For citation: Kucherov D. G., Zamulin A. L., Tsybova V.S. 2019. How young professionals choose companies: Employer brand and salary expectations. Russian Management Journal 17 (1): $29-46$.

Статья поступила в редакиию 22 января 2019 г. Принята к публикаиии 7 лиарта 2019 г. 